The $B D J$ News section accepts items that include general news, latest research and diary events that interest our

readers. Press releases or articles may be edited, and should include a colour photograph if possible. Please direct your correspondence to the News Editor, Arveen Bajaj at the BDJ, The Macmillan Building, 4 Crinan Street, London N1 9XW or by email to bdj@bda.org

\section{Helping baby arrive on time}

Periodontal therapy may reduce the risk of delivering a preterm low birth weight baby according to a new study in the Journal of Periodontology (2007; 78(5): 842-848). It showed that periodontal therapy may significantly reduce the risk of delivering a preterm low birth weight baby for women with periodontal disease.

The study looked at 328 pregnant women with periodontal disease and 122 periodontally healthy women. Periodontal treatment was preformed during the second trimester of pregnancy on 266 of the women with periodontal disease.

Sixty-two women dropped out of treatment. Postpartum follow up on all 450 subjects showed that $79 \%$ of the women with untreated periodontal disease had delivered a preterm low birth weight baby compared to only $7.5 \%$ of the periodontally treated women and $4.1 \%$ of the healthy women.

Study author Catia M Gazolla commented, 'These are important findings that we hope all pregnant women will take to their dental professionals when discussing their periodontal health.'

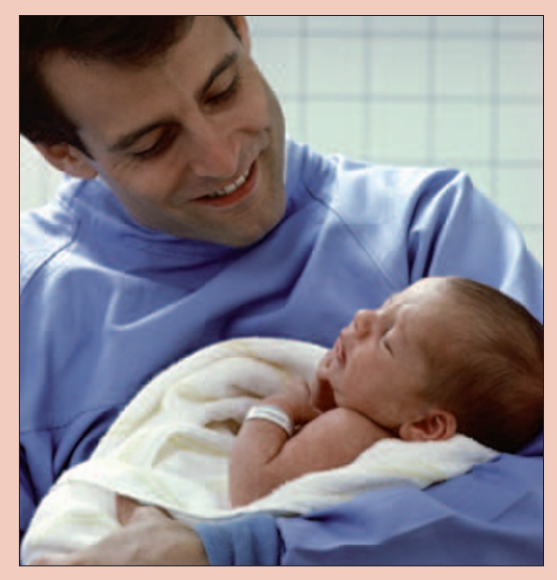

\title{
BDJ visits the Big Easy
}

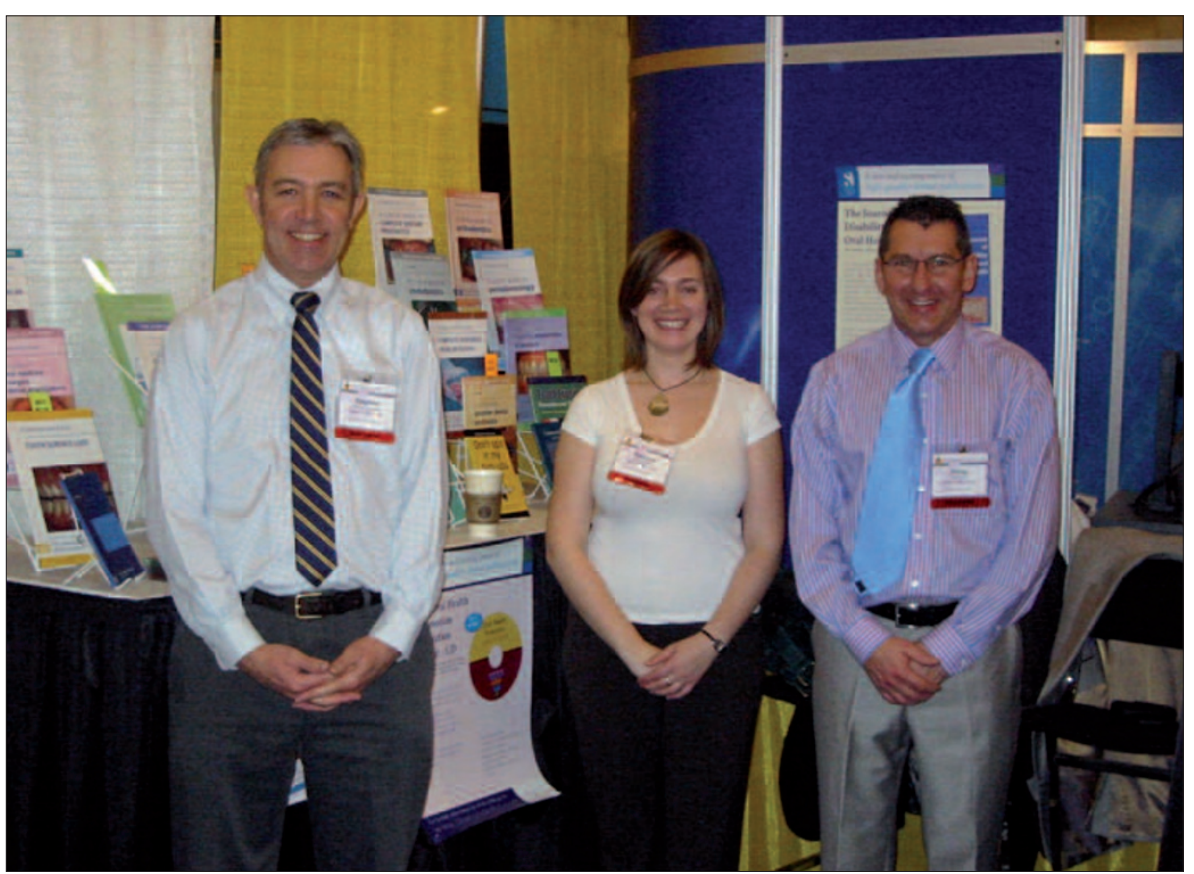

Delegates at the International Association for Dental Research 85th General Session and Exhibition, held in New Orleans recently, had the opportunity to win a small slice of British history by visiting the British Dental Journal stand. Visitors were encouraged to enter a competition to 'Win a London bus' (unfortunately just a model), with the first prize winner also taking home a year's free personal subscription to the $B D J$.

The competition proved extremely popular, with six prize winners receiving the coveted Routemaster toys. The conference was a great opportunity to raise the profile of the $B D J$ portfolio overseas, and the team were pleased with the amount of interest that was shown in the $B D J$ and the positive comments that were received.

The $B D J$ will also be present at the American Dental Association Annual Session in San Francisco from 27-30 September. If you will be attending, please come and visit us at the exhibition. Pictured above from left to right, BDJ Editor-in-Chief Stephen Hancocks OBE, Journal Editor Rowena Milan and Philip Giorgi of Stephen Hancocks Ltd at the $B D J$ stand in New Orleans.

\section{School encourages good oral health}

Children at an Oldham primary school have pearly whites to be proud of thanks to a special 'tooth friendly' scheme. St Hugh's primary school in Holts picked up its Platinum Tooth Friendly award after meeting tight criteria including not allowing sweets to be brought into school, not selling pupils food and drink which contains sugar, having a sugar free reward system, encouraging parents to provide healthy packed lunches, not celebrating birthdays with sweets and having healthy eating activities. The school is the eighth in Oldham to receive the award from Oldham Primary Care Trust's dental service. 


\section{Decay fighting technology}

American researchers have created tooth restorations using nanocomposites. In a joint research programme between at the American Dental Association's Paffenbarger Research Center and the National Institute of Standards and Technology (NIST), scientists have shown that nanotechnology has the potential to produce tooth restorations that are both stronger

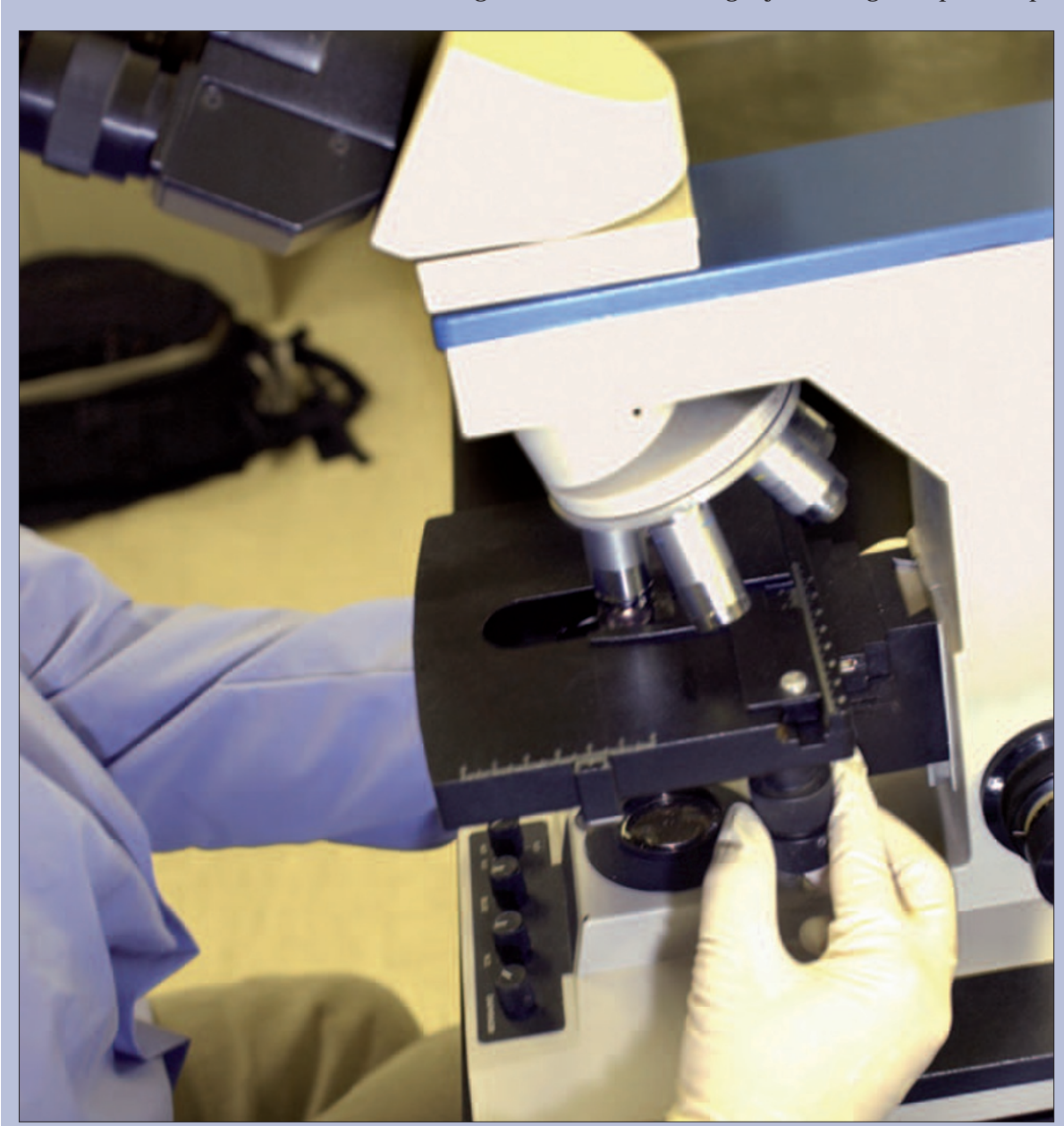

uid resin with a powder that contains colouring, reinforcement and other materials, packing the resulting paste into the cavity, and illuminating the tooth with a light that causes the paste to polymerise and harden.

For decay-fighting composite fillings, the problem arises from an additive that is included in the powder to provide a steady release of calcium and phosphate ions. These ions are essential to the long-term success of the filling because they not only strengthen the crystal structure of the tooth itself, but buffer it against the decay-causing acid produced by bacteria in the mouth. Yet the available ion-releasing compounds are structurally quite weak, to the point where they weaken the filling as a whole.

To get around this conundrum, the researchers have devised a spray-drying technique that yields particles of several such compounds, one of which is dicalcium phosphate anhydrous, or DCPA, that are about 50 nanometres across - 20 times smaller than the onemicrometre particles in a conventional DCPA powder. Because these nanoscale particles have a much higher surface to volume ratio, they are more effective at releasing ions, which means that much less of the material is required to produce the same effect. That, in turn, leaves more room in the resin for reinforcing fibres that strengthen the final filling. To exploit that opportunity, the researchers also have developed nanoscale silica-fused fibres that produce a composite resin nearly twice as strong as the currently available commercial variety. They report their findings in a recent issue of The Journal of Dental Research (2007; 86(4): 378-383). 


\section{Ten years of successful publishing celebrated}

Nature Publishing Group and the British Dental Association recently celebrated the 10th anniversary of their publishing partnership with a champagne and canapé reception in London.

The event took place at the British Dental Association's offices and featured an exhibition of original $B D J$ cover paintings by artist Joe Dixon. Commenting on the evening, Stephen Hancocks, Editor-in-Chief of the BDJ said, 'The mutually beneficial partnership between the BDA and Nature Publishing Group has not only meant a high standard of publications for BDA Members and subscribers across our suite of titles but also a valuable income stream to the Association.'

The event also marked the retirement of the BDJ's scientific advisor John Murray, who was presented with a painting by his favourite artist Alan Reed. Kim Black-Totham, BDJ Publisher said, 'The evening was the perfect celebra-

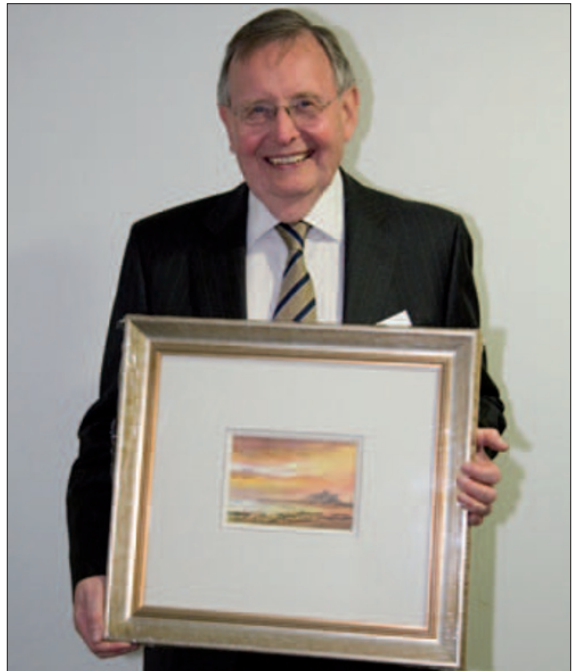

John Murray is presented with a painting to mark his retirement

tion of the strong relationship between the BDA and Nature Publishing Group. It was also wonderful to have so many people there!'

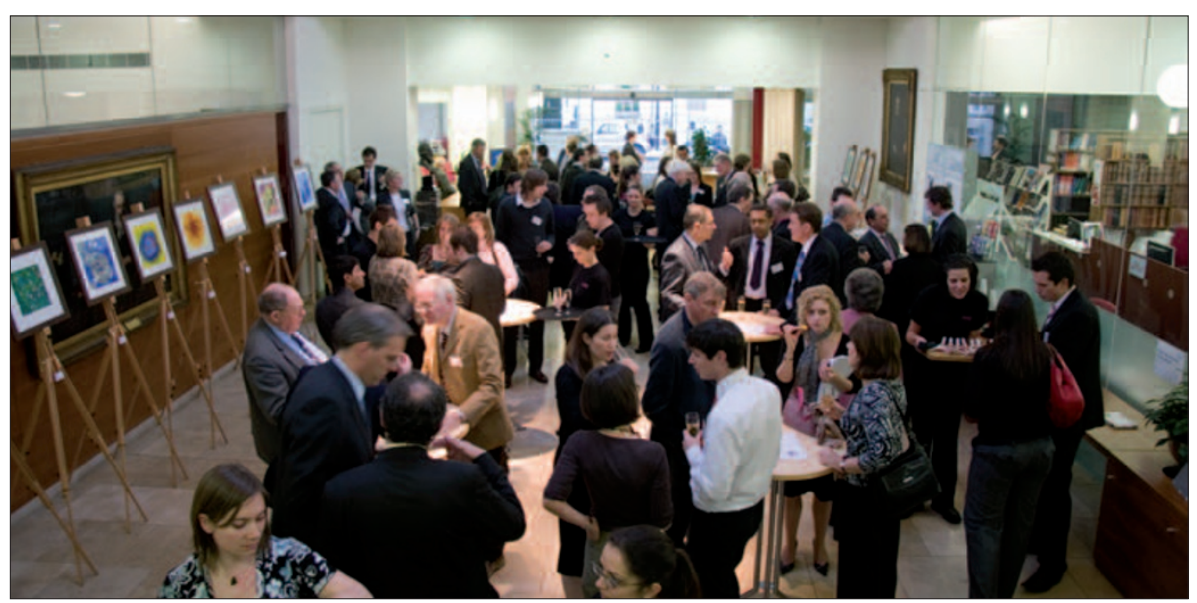

Guests enjoy champagne and canapés from Jamie Oliver's Fifteen to You

\section{New success}

Dunmurry Dental Practice were recent winners at the Lisburn City Business Awards, given to the company that displayed a strategic approach to the continued growth of the business, with quantifiable improvement in income and development.

Philip Mc Lorinan, Prinicipal and owner said, "The award that shows that by working hard as a team, we are continuing to care for our existing patients and also attract many new patients.'

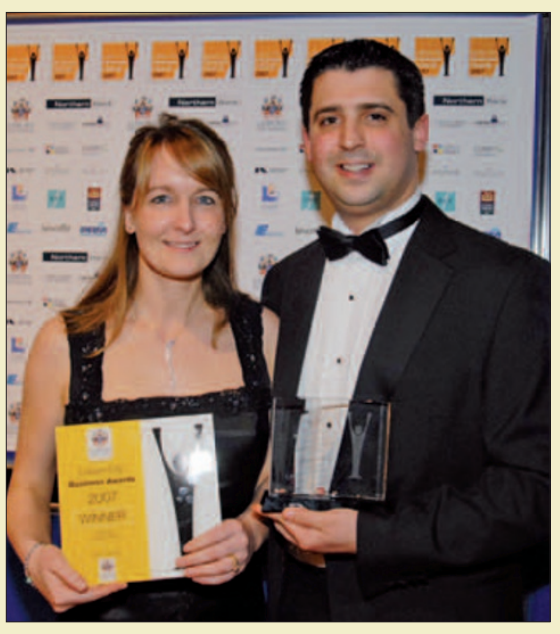




\section{DIARY}

June

14th Annual Congress of the Turkish Dental Association Date: 11-17 June 2007

Venue: Lütfi Kirdar Convention Center, Istanbul, Turkey

www.tdbkongresi.com

\section{1st Congress of International}

Association of Paediatric Dentistry

Date: 13-17 June 2007

Venue: Hong Kong Convention and

Exhibition Centre

Email: info@iapd2007.com

www.iapd2007.com

113th Meeting of the

American Dental Society of Europe

Date: 26-29 June 2007

Venue: Cameron House,

Loch Lomond, Scotland

Tel: 01413310088

www.adse.co.uk

July

BDA Armed Forces Group AGM

Date: 5 July 2007

Venue: BDA Lecture Theatre, London

Tel: 01296656469

\section{September}

4th Annual Meeting of the

European Society of Estethic Dentistry Date: Vienna, Austria

Venue: 21-23 September 2007

Email: iris.bobal@media.co.at

www.escdonline.eu

148th American Dental Association

Annual Session and Marketplace

Exhibition

Date: 27-30 September 2007

Venue: The Moscone Center,

San Francisco, USA

www.ada.org

\section{October}

Annual meeting of the Society of Craniofacial Genetics \& American Society of Human Genetics Meeting Date: 23 October 2007

Venue: Convention Center, San Diego,

California, USA

www.craniofacialgenetics.org

FDI Annual World Dental Congress

Date: 24-27 October 2007

Venue: Dubai, UAE

Email: congress@fdiworldental.org

www.fdiworldental.org

\section{On the lookout for outstanding teachers}

The Dental Defence Union (DDU), the specialist dental division of the MDU, has opened nominations for its annual Educational Awards, now in its fifth year. Students and vocational dental practitioners (VDPs) have until Tuesday 31 July to nominate the teachers whose approach most motivates and inspires them.

The Dentist Teacher of the Year, Vocational Teacher of the Year and, Dental Care Professional (DCP) Teacher of the Year will be announced at an awards ceremony in central London on 7 November 2007. Winners and runners-up will be awarded £250 each and in addition, the overall winners in each category will receive $£ 1,000$ towards the cost of educational materials for their schools or VT schemes.

Rupert Hoppenbrouwers, Head of the DDU, said, 'The high standard of dental education in the UK represents an important point of continuity in what is a turbulent period for the profession, so it is important that the work of dental teachers should be recognised and valued. After all, no other group has such an opportunity to shape the working practices and ethics of future genera-

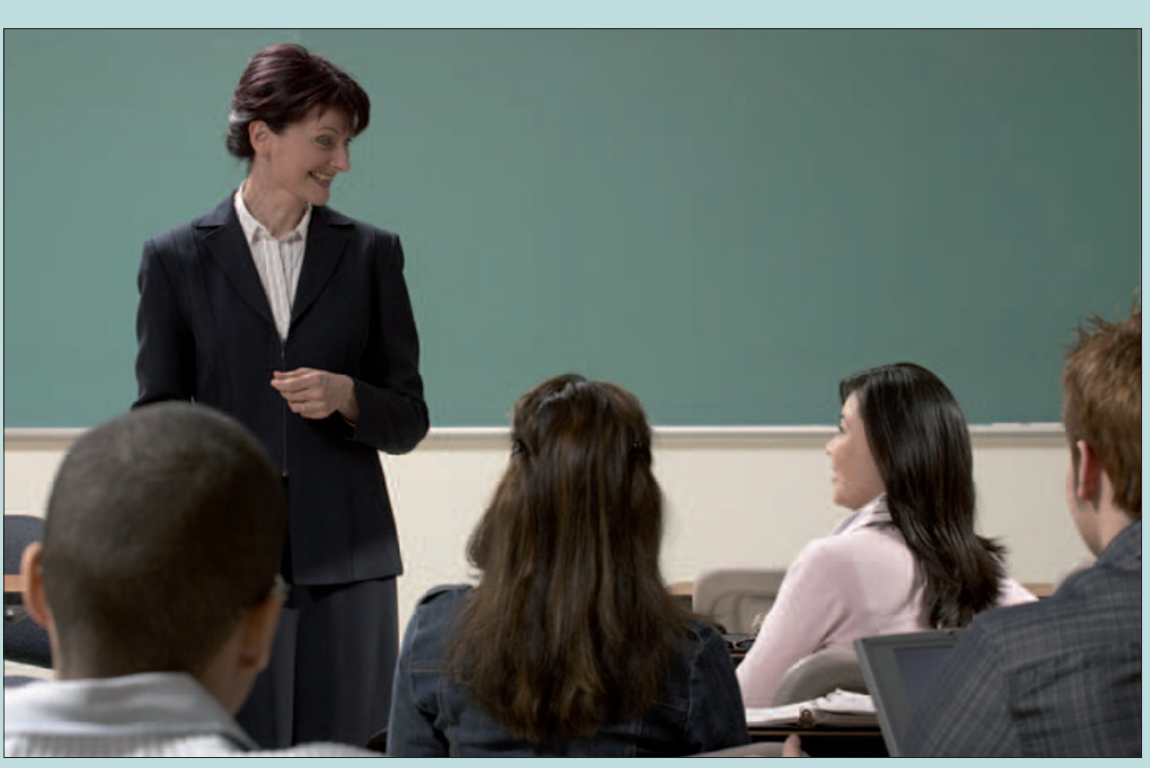

\section{Dress to impress for charity}

Dental charity Dentaid is holding its annual Dress Up 4 Dentaid Day on 6 July 2007. Dental practices taking part can come to work in something other than their usual attire in order to raise funds for the charity. Previous participants have dressed up, dressed down or adopted a theme for the day and Dentaid will be ions of dental professionals. We hope that students will again take a moment to nominate a teacher who has particularly motivated or inspired them.'

Students and VDPs in the UK and Ireland can nominate a teacher by completing a nomination form, which is then reviewed by the DDU and a panel of judges. Forms are available on the DDU website (www.the-ddu.com/ dduawards) or from a DDU dental liaison manager. Students and VDPs who submit an entry will be entered into a prize draw to win an iPod. Awards will be judged across a number of criteria, including knowledge of the subject and ability to motivate. The DDU awards main sponsor is Dentsply, while the BDA is also supporting the initiative.

The winners of the DDU Educational Awards in 2006 were Mark Greenwood from the University of Newcastle, Mike Kelly from Kent, Surrey and Sussex Deanery and Sheila Phillips of the School of Professionals Complementary to Dentistry, Portsmouth who won Dentist Teacher of the Year, Vocational Trainer of the Year and DCP Teacher of the Year respectively. holding a competition to find the practices with the Best Theme/Costume, Best Dress up Day event and Top Fundraisers. To enter register online at www.dentaid.org or contact Dentaid for an application form and fundraising pack on 01794324249 or email info@dentaid.org. Last year's winners can be viewed on www.dentaid.org. 


\section{New specialist programme}

An MSc in Maxillofacial \& Craniofacial Technology has been launched at King's College London Dental Institute. This is currently the only Masters Degree programme of its type in the United Kingdom and Europe, and is also seen as providing training for exceptional students who may wish to consider registration for a PhD in Maxillofacial and Craniofacial materials and technology.

Speaking at a reception for the launch, the programme co-ordinator Dr Trevor Coward explained, 'The programme provides opportunities forstudents to develop and demonstrate extended knowledge and understanding and advanced skills including anatomy, histology, pathology of the dental, oral and facial tissues, research methodology, intra/extra oral implantology, materials science, oncology, craniofacial abnormalities, and digital technology. The course consists of treating patients through diagnosis and treatment planning, restoration of missing tissues including clinical and laboratory procedures, and surgical planning techniques.'

The programme has four main components; taught course (laboratory procedures, lectures, tutorials and seminars); clinical (theatre sessions, consultation clinics and patient treatment); distance learning (five assignments online); and research (literature review, experiment work and a dissertation).

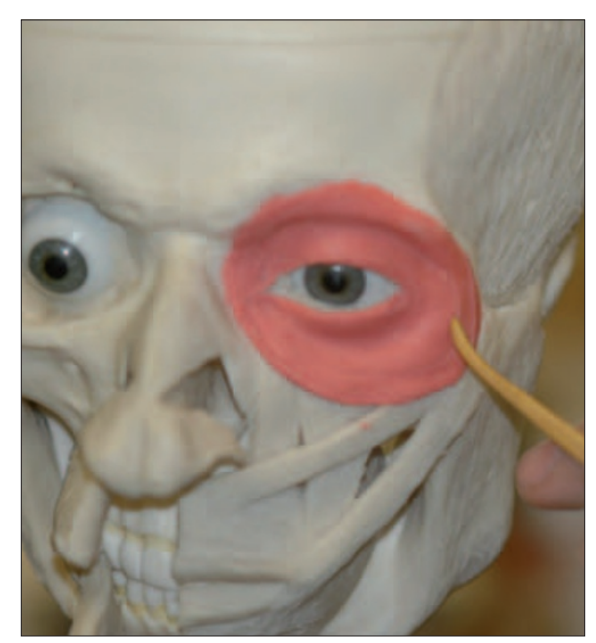

The programme - which commenced in October 2006 and finishes September 2008 - is part-time over two years, of which one day is designated to distance learning. In addition, the Dental Institute has an international collaboration with the Anaplastology course in Chicago and in the near future will be providing tutorials, lectures and seminars via the internet allowing interaction between students. The reception was attended by students presently on the course, key members of staff from King's College London, King’s College Hospital and Guy's and St Thomas' Trust, many of whom have given teaching and surgical support and by the companies supplying materials for the course.

\section{New decontamination guidance}

The first in a series of new guidance for dental professionals in Scotland on the decontamination of instruments has been launched by the Scottish Dental Clinical Effectiveness Programme (SDCEP). The first instalment of Decontamination Into Practice includes advice on the cleaning of dental instruments and information of relevance to the decontamination process.

SDCEP is a National Dental Advisory Committee (NDAC) initiative supported by NHS Education for Scotland (NES). It aims to aid improvements in the quality of dental care by providing user-friendly guidance in specific Scottish priority dental topics.

NDAC Chairman, Professor Jeremy Bagg said, 'A survey of dental practices in Scotland identified a need for clear, practical guidance on decontamination. Effective decontamination is essential for the provision of safe patient care and its importance is well recognised by the profession. This has been further highlighted recently by the General Dental Council which identified decontamination as a core subject for continuing professional development. I believe that dental teams in Scotland will find this guidance to be a valuable aid to enhancing standards of clinical care.'

The Scottish Dental Clinical Effectiveness Programme was established in 2004 with funding from the Chief Dental Officer for Scotland. Since then, it has undertaken to develop guidance in seven key clinical areas. Decontamination Into Practice is the second SDCEP publication with several more projects expected to come to fruition in the coming year. Further information on the work of SDCEP is available on its website, www.scottishdental.org/cep. 